\title{
Centenario de El suicidio, de Émile Durkheim (1897-1997)
}

\author{
Seminario de fundamentos clásicos de la sociología. \\ Programa de doctorado de sociología avanzada \\ Universitat de Barcelona. Departament de Sociologia \\ Avinguda Diagonal, 690. 08034 Barcelona. Spain \\ demiguel@cco.ub.es
}

\section{Resumen}

Se cumplen cien años de una de las obras clave de la sociología. El presente artículo es una reflexión documentada bibliográficamente sobre el centenario de uno de los estudios sociológicos más influyentes en la historia de esta ciencia: El suicidio de Émile Durkheim, publicado originalmente en 1897. El artículo consta de tres partes: se inicia con la imporancia del estudio de Durkheim; en la segunda parte se analiza una selección de textos clave del libro, poniéndolo en relación con la situación social cien años después; finalmente se presenta una bibliografía documentada sobre las obras de Durkheim en español.

Palabras clave: Durkheim, suicidio, metodología, individuo/sociedad, comunidad.

\section{Abstract}

Since 100 years now, one of the most important books on sociology was published. This article is a well informed analysis on the centenary of one of the most influential sociological studies in the history of Sociology — the book The Suicide by Émile Durkheim, first published in 1897. This article is divided into three parts. It begins with the importance of studying Durkheim. The second part, deals with a selection of key fragments of The Suicide in relation to the social situation 100 years later. Finally, there is a commented bibliography about Durkheim's boooks in Spain.

Key words: Durkheim, suicide, methodology, individual/society, community.

\section{Sumario}

Para una relectura de El suicidio un siglo después

El suicidio de El suicidio

La nota misteriosamente desaparecida

Dualismo de la sociedad

Causas e intenciones

Desintegración de lo social

Regularidad del suicidio

La mujer, costilla o columna
Nueva idea de sociedad

Moral y conciencia colectiva

Relaciones amor-odio

La criminal

Más allá del bien y del mal

Progreso de la sociedad

Herencia de los clásicos

Bibliografía 
Desde hace algún tiempo Émile Durkheim está de moda ${ }^{1}$. El sociólogo francés nace el 15 de abril de 1858 en Épinal y muere a los 59 años — de un ataque al corazón- el 17 de noviembre de 1917 en París. En el año de 1997 se cumplió un siglo de su cuarto libro: Le suicide: Étude de Sociologie, publicado en París por Félix Alcan, en $1897^{2}$. Es quizás la obra que más contribuye a la institucionalización de la sociología como ciencia empírica. El libro es un acontecimiento intelectual sin precedentes para la época. Marca un siglo de profesión sociológica. El libro lo leen todavía estudiantes y profesores como una pieza esencial de reflexión dentro de nuestra profesión.

El libro se traduce al castellano en $1928^{3}$, es decir, veintitrés años antes que al inglés 4 . La edición española de El suicidio: Estudio de Sociología "por Émile Durkheim, profesor de la Facultad de Letras de París» incluye un estudio preliminar sobre la "Etiología del Suicidio en España» escrito por Mariano RuizFunes, traductor del libro", con la dedicatoria "A Constancio Bernaldo de

1. El presente estudio está escrito por el Seminario de Fundamentos Clásicos de la Sociología, de la Universidad de Barcelona, compuesto (en orden alfabético) por Núria Arbussà, Sonia Arnó, Marta Caballero, Jordi Caïs, Àlex Díaz, Xavier Escandell, Francisco J. Granados, Luis M. López Dávila, Marga Marí-Klose, Jesús M. de Miguel, Anna Nos, Víctor Renobell, Juan C. del Río y Núria Sorio.

2. Antes había publicado Quid secundatus politicae scientiae instituendae contulerit (en 1892), De la division du travail social: Étude sur l'organisation des sociétés supérieures (en 1893), y Les règles de la méthode sociologique (en 1895); los dos últimos publicados por Félix Alcan, en París. La primera edición de El suicidio, en francés, en 1897 viene introducido por doce páginas correspondientes al prefacio del propio Durkheim (numeradas en romano) y $462 \mathrm{p}$.

3. Émile Durkheim, El suicidio: Estudio de Sociología (Madrid: Editorial Reus, SA y Centro de Enseñanza, 1928), 450 p. La edición actual que más se maneja en España es de la editorial Akal, Akal Universitaria, Serie Sociología, primera edición en 1982, cuarta en 1995. Es una edición facsímil, es decir, copiada exactamente de la edición española de 1928, incluyendo las erratas de la edición original de 1928. Tiene un estudio previo diferente por Lorenzo Díaz Sánchez (p. V-XXIII).

4. El libro no se publica en inglés hasta 1951 Suicide: A Study in Sociology (Glencoe, Illinois: Free Press of Glencoe, 1951), 405 p., traducido por John. A. Spaulding y George Simpson. Está editado y con una introducción de G. Simpson. Se publica en Londres al año siguiente (Routledge and Kegan Paul, 1952). Cuatro años antes se había publicado una traducción de unas pocas páginas en la revista University Observer (invierno 1947) con una introducción de Sebastian de Grazia. Inexplicablemente El suicidio se tarda mucho en traducir al inglés (y poco al español), aunque otras obras de Durkheim ya se conocían antes en inglés, como Las formas elementales de la vida religiosa, en 1915, La división del trabajo social, en 1933, y Las reglas del método sociológico, en 1938. Pitirim Sorokin escribe sobre Durkheim ya en 1928, Robert K. Merton, en 1934, y Talcott Parson, en 1937. La American Journal of Sociology edita un número monográfico en el centenario de su nacimiento, en 1958 (mayo, número 62) titulado "Durkheim-Simmel Commemorative Issue». El mundo francés obviamente le ha dedicado mucha más atención, como el número monográfico "A propos de Durkheim» de la Revue Française de Sociologie, vol. 17, núm. 2, p. 155-375.

5. En las páginas I a XXXIX. Mariano Ruiz-Funes es en esa fecha catedrático de Derecho Penal en la Universidad de Murcia. Tiene una extensa bibliografía criminológica con libros como Ideas penales de Anatole France, La protección penal de la electricidad, La protección penal de la energía genésica, Notas sobre la celda, La criminalidad y las secreciones internas, La pena de muerte en Italia, El proyecto de ley argentino sobre el estado peligroso, El suicidio y el homicidio en España, y el Derecho Penal de los soviets. 
Quirós, que nos mostró el camino» ${ }^{6}$. El estudio preliminar de treinta y nueve páginas se justifica así: "Hemos redactado estas glosas a la estadística española sobre la causalidad del suicidio en nuestro país, sistematizando la inercia de sus cifras y dando a su mutismo desconsolador, el vehículo animado de la palabra, que presta, a la sequedad de los números, una dolorosa elocuencia» 7 . No parece que el catedrático Mariano Ruiz-Funes entendiese bien lo que Durkheim había escrito y razonado en El suicidio de 1897 . La traducción se realiza directamente del francés pero de la segunda edición del libro, es decir, la de 1912 (París, Alcan igualmente).

El libro se publica en 1928, pero es olvidado por los estudiosos españoles hasta la década de los ochenta ${ }^{8}$. Carlos Moya es uno de los pocos sociólogos que se interesa de nuevo en España por la obra de Durkheim ${ }^{9}$. Mientras tanto, en Latinoamérica el libro de El suicidio despierta interés, y en 1965 hay una buena traducción en Argentina ${ }^{10}$.

La edición española de 1928 contiene un misterio que hasta ahora nadie ha resuelto. En el prólogo Durkheim incluye una nota a pie de página que en la edición española aparece así: «(1) Ya demostraremos más adelante (página , nota) que este punto de vista, lejos de excluir toda libertad, es el único medio de conciliarla con el determinismo que ponen de relieve los datos de la estadística»11. La página aparece en blanco, y por lo tanto nadie puede encontrar la nota tan importante a la que se refiere Durkheim en su obra. Luego se verá dónde está la famosa nota extraviada.

Para entender a Durkheim, y para explicar mejor el tema básico de las tensiones entre individuo y sociedad en el centenario de El suicidio, es básico leer

6. Se refiere a Constancio Bernaldo de Quirós, autor de libros como Bandolerismo y delincuencia subversiva en la baja Andalucia (Madrid: Fortanet, 1913), El espartaquismo agrario andaluz (Madrid: Reus, 1919), Figuras delincuentes (Madrid: Góngora, sin fecha), o del libro con Luis Ardila, Criminología del campo andaluz: El bandolerismo (Madrid: Gráfica Universal, 1934). Claramente se identifica a El suicidio como un libro de criminología, idea con la que Durkheim no estaría de acuerdo.

7. De la edición española de 1928 , p. II.

8. Salvo el estudio de Jesús M. de Miguel, El ritmo de la vida social (Madrid: Tecnos, 1973), 356 p. El libro se subtitula Análisis sociológico de la dinámica de la población en España, pero tiene una primera parte extensa sobre "La aportación teórica de Emile Durkheim» (p. 2580), y una tercera parte directamente sobre «El suicidio» (p. 274-356), con un análisis sobre el suicidio en España.

9. Carlos Moya, «Emile Durkheim: La autonomía metodológica de la Sociología y los orígenes del análisis estructural-funcional», Revista Española de la Opinión Pública, 8 (1967). Al año siguiente publica: «La aportación funcionalista de Durkheim al diagnóstico social positivo", Revista Española de la Opinión Pública, 11 (1968).

10. Emilio Durkheim. El suicidio: estudio de sociología. Buenos Aires: Editorial Schapire, 1965 , 315 p. En «versión directa del francés» por Lucila Gibaja. No es una reproducción de la edición española de 1928, pues la traducción difiere un poco. No se señala si es traducción de la primera francesa o de la segunda. Suponemos que es de la primera.

11. Es la página X de la edición de 1928. La edición facsímil de la Editorial Akal de 1982 repite la misma anotación en que falta la página y la nota. La edición argentina (Editorial Schapire) de 1965 complica aún más el asunto de la nota extraviada, pues señala que está en la página 364, en cambio el libro en esa edición argentina sólo tiene 315 páginas. 
un artículo breve de Durkheim publicado en 1914, titulado «Le dualisme de la nature humaine et ses conditions sociales». El artículo se publica en una revista italiana, Scientia, en marzo de 191412 . No existe una traducción al castellano de este artículo clave en el pensamiento durkheimiano. En inglés se publica en $1960^{13}$. La quintaesencia del artículo es que «nous ne pouvons donc comprendre les choses sans renoncer, en partie, à en sentir la vie, et nous ne pouvons la sentir sans renoncer à la comprendre» ${ }^{14}$. Es todo un testamento sociológico, apropiado para este centenario suicida.

\section{Para una relectura de El suicidio un siglo después}

Está de moda Durkheim, pero no el suicidio. El suicidio es un libro capital en la profesión, pero poco leído. A pesar de ello es un «estudio de sociología» (como le gustó resaltar al propio Durkheim, subtítulo que desagradecidamente no se incluye en la edición española actual) preñado de ideas. Conviene releer El suicidio ahora que los paradigmas dominantes de la sociología están en decadencia, y que se mantiene un nivel de «ciencia normal». Una forma de acercarse a El suicidio es precisamente a través de lo que sus textos sugieren para la interpretación de la sociedad actual. Eso es precisamente lo que Durkheim pretende; mucho más que un estudio de suicidas ${ }^{15}$.

\section{El suicidio de El suicidio}

El prefacio plantea ya el resumen de toda la argumentación de Durkheim:

Nos parece difícil que no se desprenda, de cada página, de este libro, la impresión de que el individuo está dominado por una realidad moral que lo supera: la realidad colectiva. Cuando se vea que cada pueblo tiene una cifra de suicidios que es propia de él; que esta cifra es más constante que la de la mortalidad general; que si evoluciona, lo hace siguiendo un coeficiente de aceleración,

12. "Le dualisme de la nature humaine et ses conditions sociales», Scientia, vol. 15, núm. 34-2 (marzo 1914), p. 206-221.

13. Así se puede ver en el libro Émile Durkheim, 1858-1917, publicado por Ohio State University Press. La edición más accesible es la de Kurt H. Wolff, ed., Émile Durkheim et al. Essays on Sociology and Philosophy (Nueva York: Harper Torchbooks, Harper \& Row, 1964), 463 p. El libro incluye trece breves estudios sobre Durkheim ("with appraisals of Durkheim's life and thought by...») escritos, entre otros, por Lewis A. Coser y Talcott Parsons. Entre las traducciones que incluye de obras de Durkheim está el famoso artículo de 1914, una carta a Radcliffe-Brown, prefacios a L'Année Sociologique, etc. El artículo en cuestión se puede ver en las páginas 235-340 con el título de «The dualism of human nature and its social conditions".

14. "No podemos pues entender las cosas sin renuncia, en parte, a sentir la vida, y no podemos sentirla sin renunciar a comprenderla» (página 211 de la edición original).

15. Escrito por Núria Arbussà, Sonia Amó, Marta Caballero, Jordi Caïs, Àlex Díaz, Xavier Escandell, Francisco J. Granados, Luis M. López Dávila, Marga Marí-Klose, Jesús M. de Miguel, Anna Nos, Víctor Renobell, Juan C. del Río y Núria Sorio. 
que es peculiar de cada sociedad; que las variaciones, porque pasa en los diferentes momentos del día, del mes, del año, no hacen más que reproducir el ritmo de la vida social; cuando se compruebe que el matrimonio, el divorcio, la familia, la sociedad religiosa, el ejército, etc., influyen en ella según leyes definidas, y que algunas de ellas pueden ser expresadas en forma numérica [...], se renunciará a ver en estos estados y en estas instituciones, imaginarias fórmulas ideológicas sin virtud y sin eficacia. Por el contrario, se tendrá la sensación de que se trata de fuerzas reales, que viven y que obran y que por el modo que tienen de determinar al individuo, testimonian suficientemente que no dependen de él o, cuando menos, que si él entra, como elemento, en la combinación que de estas fuerzas resulta, acaban por imponerse, a medida que se van desenvolviendo. En estas condiciones, se comprenderá mejor cómo la sociología puede y debe ser objetiva, puesto que dirige sus investigaciones a realidades, tan definidas y consistentes como aquéllas de que tratan el psicólogo y el biólogo ${ }^{16}$.

Lo más dramático de este párrafo inicial, casi resumen de todo el libro, es la tensión entre individuo e individua y sociedad. El ser humano se ve continuamente desbordado, ahogado, agobiado, por la realidad colectiva. Durkheim pretende hacer algo más que un estudio del suicidio, su objetivo es bastante más importante. Pretende demostrar que la sociedad existe, y que si las personas no se matan es porque pertenecen a una sociedad que les protege, bien sea la familia, la religión o la sociedad global. Con esta demostración laboriosa demuestra que existe la sociedad, y por lo tanto da pie a la institucionalización de la sociología... su objetivo secreto.

Pero no sólo existe la sociedad, sino que cada tipo de sociedad marca su propio ritmo. Es la expresión afortunada del ritmo de la vida social que en España da origen a un libro durkheimiano con ese mismo título ${ }^{17}$. La sociedad desarrolla fuerzas reales que determinan la conducta del ser humano. La estructura de la sociedad obliga a los seres humanos a actuar de una forma determinada, incluso a pensar ideas fijas. Es un razonamiento más marxista que funcionalista, a pesar de la utilización masiva posterior de Durkheim para fundar el estructural-funcionalismo. Pero lo que importa a Durkheim es que existen leyes sociales, que incluso pueden expresarse en números, como coeficientes de prevención o de tendencia al suicidio ${ }^{18}$. Aquí aparece la segunda gran idea del libro, que la sociología es una ciencia que puede y debe ser objetiva, que puede y debe analizar las leyes de la sociedad, incluso en forma numérica como

16. Todas las citas son de la cuarta edición de Akal Editorial (1995), que es la más accesible en castellano, Durkheım, Émile (1995). El suicidio. Madrid: Akal Ediciones, 450 p. Es la cuarta edición; la primera es de 1982. La cita aparece en el prólogo, en la página XXX.

17. Es la tesis doctoral española de Miguel, Jesús M. de (1973). El ritmo de la vida social. Madrid: Tecnos, $356 \mathrm{p}$.

18. Tres décadas después se expresaría la misma idea de que la sociedad moderna supone un coste de malestar, y que las personas débiles que no pueden resistirlo se suicidan. La idea es de Freud, Sigmund (1930). El malestar de la cultura, más bien «el descontento de la civilización». 
las demás ciencias. Es pues un esfuerzo titánico por demostrar que existe la sociedad como una realidad supraindividual, y que es posible definir leyes sociales. El suicidio no es más que una excusa para demostrar ambas hipótesis. En ese sentido nada parece importarle a Durkheim menos que el suicidio, o incluso los suicidas y las suicidas. Se trata — como en otras ciencias- de analizar la normalidad a través de la anormalidad. Aunque sobre ese tema Durkheim avanza también con ideas innovadoras.

\section{La nota misteriosamente desaparecida}

En la página XXX del prólogo (en realidad es un prefacio) de la edición española actual de El suicidio se hace referencia a una enigmática nota que los ratones de la tipografía se comieron. «(1) Ya demostraremos más adelante (página , nota) que este punto de vista, lejos de excluir toda libertad, es el único medio de conciliarla con el determinismo que ponen de relieve los datos de la estadística» ${ }^{19}$. La referencia a la página aparece en blanco, y no se sabe a qué se refiere. Esta misteriosa nota de El suicidio se encuentra al final del capítulo primero de la tercera parte del libro. Dice así:

(1) Sin querer plantear una cuestión de metafísica, que no hemos de resolver, haremos notar que esta teoría de la estadística no obliga a negar al hombre toda especie de libertad. Deja, por el contrario, la cuestión del libre albedrío mucho más entera que si se hace del individuo la fuente de los fenómenos sociales. En efecto, cualesquiera que sean las causas a las que es debida la regularidad de las manifestaciones colectivas, no pueden dejar de producir sus efectos donde se encuentren; porque, de otro modo, se vería variar estos efectos caprichosamente, siendo así que son uniformes. Por lo tanto, si son inherentes al individuo, no pueden dejar de determinar necesariamente a aquellos en quienes residen. De consiguiente, con esta hipótesis, no se ve el medio de escapar al determinismo más riguroso. Pero no ocurre lo mismo si esta constancia de los datos estadísticos proviene de una fuerza exterior a los seres humanos. Porque ésta no determina a unos sujetos más bien que a otros. Ella reclama ciertos actos en número definido, no exige que estos actos procedan de éste o de aquél. Se puede admitir que determinados sujetos la resisten y que se cumpla otros. En definitiva, nuestra concepción no tiene otro efecto que añadir a las fuerzas físicas, químicas, biológicas y psicológicas, fuerzas sociales que actúan sobre el hombre desde fuera, lo mismo para que ocurra otra cosa con aquéllas. La cuestión se plantea en los mismos términos para las unas y para las otras. Cuando se declara un foco de epidemia, su intensidad predetermina la mortalidad que de él resultará; pero no por eso están designados los que deben ser atacados. La situación de los suicidas no es otra respecto a las corrientes suicidógenas ${ }^{20}$.

19. La edición facsímil de la Editorial Akal de 1985 repite la misma anotación, en que falta la página y la nota, de su edición de 1982 que mencionamos en nuestra nota 11 .

20. El suicidio, p. 358 (en la edición española de 1985). 
En este texto Durkheim reflexiona sobre las influencias que ejercen las características de la sociedad. Indica que, dada la evidencia mostrada por los resultados del análisis estadístico, las repercusiones ocasionadas por esas características son deterministas respecto al conjunto de miembros de la sociedad. Unas características de la sociedad ocasionan otros caracteres de la misma, pero no son deterministas respecto a cada miembro de la sociedad como individuo o individua. El análisis de Durkheim ni se basa en individualidades ni sus resultados se refieren a seres humanos. Tal «socialización» del origen y del destino de las influencias de las características de la sociedad no supone, como indica Durkheim, una limitación de la libertad individual — capacidad de acciónde los miembros de la sociedad. Sí exime al individuo y a la individua de responsabilidad directa en lo referente a las causas y efectos de las características de la sociedad.

En la actualidad estas cuestiones tienen continuidad en las ciencias sociales. Los axiomas de la teoría de la elección racional inducen a una cierta falta de consideración de las influencias de la sociedad - de un pensamiento colectivo - sobre los seres humanos en el proceso de decisión de sus acciones. Este enfoque se contrapone a la perspectiva sociológica de Durkheim. Una alternativa más próxima a las tesis durkheimianas de abordar la acción individual es la consideración de las instituciones culturales en el proceso de pensamiento realizado por los miembros de la sociedad ${ }^{21}$. Esta perspectiva afirma el origen social de las categorías cognitivas en función de las cuales se toman las decisiones individuales. Ello no implica una influencia determinista de la cultura sobre los seres humanos, quienes ejercen su racionalidad de modo independiente al elegir si reforzar o subvertir, favorecer o bloquear, las alternativas que les vienen dadas por la estructura institucional en la que están incorporados. Es preciso avanzar en el estudio de las instituciones que configuran el entorno social, y en la manera en que éstas son fomentadas y percibidas por las personas 22 .

\section{Dualismo de la sociedad}

El lector y la lectora, al enfrentarse con las obras de Durkheim, debe intentar observar más allá de lo que parece evidente para vislumbrar el proyecto teórico que se esconde en el conjunto de la obra de este sociólogo. A primera vista, Durkheim, de forma consciente y deliberada, trata de construir un sistema metodológico coherente que sirva de herramienta para estudiar la sociedad. La sociología es una ciencia que puede y debe ser objetiva, cuyo objetivo es

21. Una institución es mínimamente una convención que surge del interés de las partes intervinientes en que exista una norma que asegure la coordinación, que evita el conflicto de intereses entre ellas y la intención de desvío que ocasionaría descoordinación. (Véase, por ejemplo, Lewis, D. (1968). Convention: A Philosophical Study. Cambridge, Mas.: Harvard University Press.)

22. Douglas, M. (1996). La aceptabilidad del riesgo en las ciencias sociales. Barcelona: Paidós. 
analizar las leyes de la sociedad, incluso en forma numérica como las demás ciencias.

Varias décadas después de la muerte de Durkheim, un científico mediocre, aunque gran comunicador y magnífico escritor de ciencia ficción, llamado Isaac Asimov escribe Fundación. Esta novela, que está considerada como una de las mejores obras de ciencia ficción en la actualidad, versa sobre una ciencia ficticia llamada psicohistoria. Asimov, utilizando conceptos no matemáticos, define la psicohistoria como «la rama de las matemáticas que trata sobre las reacciones de conglomerados humanos ante determinados estímulos sociales y económicos [...] Implícita en esta definición está la suposición de que el número de humanos es suficientemente grande para un tratamiento estadístico válido [...] Otra suposición necesaria es que el conjunto humano debe desconocer el análisis psicohistórico a fin de que su reacción sea verdaderamente casual» ${ }^{23}$. Asimov no llama a esta ciencia sociología para no ofender a los sociólogos ni a las sociólogas. Sin embargo, cabe preguntarse si Durkheim se hubiera sentido ofendido ante esta definición de sociología, puesto que parece evidente que la psicohistoria de Asimov es el ideal de sociología para Durkheim. Una relectura meticulosa de El suicidio quizás ofrezca respuesta.

El estudio de Durkheim sobre el suicidio es quizá el ejemplo más notable del método de análisis de la sociedad que propone dos años antes en Las reglas del método sociológico. En El suicidio Durkheim se interesa por variaciones en las tasas de suicidio entre grupos sociales diferentes. Utiliza estadísticas ya disponibles en la última década del siglo pasado. La mayoría de ellas procedentes de países europeos, aunque también dispone de información limitada de otras sociedades. El repertorio de datos que utiliza está bien delimitado. Durkheim define con claridad el objeto de estudio y lo separa de otros fenómenos relacionados. Define el suicidio como «todo caso de muerte que resulte directa o indirectamente de un acto positivo o negativo, ejecutado por la propia víctima, a sabiendas de que habría de producir ese resultado» 24 . Posteriormente, el autor se pregunta si el suicidio definido de esta manera interesa al sociólogo y a la socióloga.

Puesto que el suicidio es un acto individual que únicamente afecta al individuo, parecería que dependiera exclusivamente de factores individuales y que, por consiguiente, fuese de la sola incumbencia de la psicología. [Sin embargo] si en lugar de ver en ellos nada más que acontecimientos particulares y aislados entre sí, que deben ser examinados separadamente, consideramos en conjunto los suicidios ocurridos en una sociedad dada, durante una unidad de tiempo determinada, comprobaríamos que el total así obtenido no es una simple suma de unidades independientes, una mera colección, sino que constituye por sí mismo

23. Asimov, Isaac (1986). Fundación. Barcelona: Plaza \& Janés, 261 p. La cita se refiere a las p. 27-28. La edición original en inglés es de 1951.

24. El suicidio, p. 5. 
un hecho nuevo y sui generis que tiene su unidad y su individualidad y, por consiguiente, su naturaleza propia, y que, además, esa naturaleza es eminentemente social 25 .

Durkheim define el suicidio y sus causas como hechos sociales. El suicidio sólo se explica de forma sociológica, y no por motivaciones individuales, ya que se produce en función de condiciones sociales. La unidad de análisis es la sociedad, y no el ser humano. Precisamente este énfasis que pone en «la sociedad» permite responder la pregunta que se plantea en el párrafo anterior.

Según Durkheim la sociedad es una realidad ambigua. La sociedad y los fenómenos sociales no pueden reducirse a fenómenos individuales. Sin embargo, la sociedad es algo más que la suma de un grupo de seres humanos, es un todo dinámico que debe ser entendido de manera autónoma y que tiene existencia propia. La sociedad es un ente mayor y más complejo que la mera suma de sus partes. Es sobre todo un universo moral. El servicio más importante que la sociedad presta a sus miembros es desarrollar e imponer una definición particular de realidad, así como una organización moral del mundo. Para entender la conexión entre el ser humano y la sociedad es crucial el concepto durkheimniano de conciencia colectiva. Es a través de la solidaridad derivada de esa conciencia colectiva que los seres humanos tienen la sensación de enfrentarse a una realidad sólida y significativa, y no al caos.

«Sociedad» es el concepto más importante en el trabajo de Durkheim. Tal y como comenta Robert Bellah en la introducción de su libro Emile Durkheim On Morality and Society:

No hay ninguna palabra en los escritos de Durkheim que sea más difícil y menos común que sociedad. Hurgar en los significados y niveles semánticos múltiples de esta palabra podría ser equivalente a entender el pensamiento global de Durkheim. A veces la palabra es simple y obvia; se refiere a algún grupo social específico. Otras veces su significado es más oscuro y misterioso ${ }^{26}$.

Afirmar que Durkheim es tan sólo el creador de una metodología, o el precursor del funcionalismo, es mostrar una visión miope y limitada de su trabajo. Durkheim se habría ofendido si Isaac Asimov hubiera bautizado su ciencia ficticia con el nombre de sociología y no con el de psicohistoria. Durkheim va mucho más allá de la mera creación de una herramienta de análisis; el objetivo de su sociología es crear un marco teórico que ofrezca maneras de comprender las cuestiones morales fundamentales a partir de la investigación científica. 


\section{Causas e intenciones}

Cuando algo sorprende se tiende de manera inmediata e inevitable a buscar su causa. Se abandona el objeto causante de asombro y se traslada la atención a un objeto anterior que pueda dar razón de él. Durkheim empieza El suicidio ofreciendo también una clasificación de los suicidios según las causas que los provocan. Su clasificación etiológica presupone explicaciones causales, y dedica el resto del libro a demostrar su fundamento.

Sólo puede haber tipos diferentes de suicidios en cuanto sean diferentes las causas que dependan. Para que cada uno tenga una naturaleza propia, se precisan condiciones de existencia peculiares de él. Un mismo antecedente o un mismo grupo de antecedentes no puede producir ahora una consecuencia y luego otra, porque entonces la diferencia que distinguiera la segunda de la primera, carecería ella misma de causa, constituyendo una negación del principio de causalidad. Toda distinción específica, comprobada en las causas, implica, pues, una distinción semejante entre los efectos. En consecuencia, podemos constituir los tipos sociales del suicidio clasificándolos, no directamente y según sus caracteres previamente descritos, sino ordenando las causas que los producen. Sin que nos preocupemos por saber a qué se debe la diferencia de los unos y los otros, investigaremos en seguida cuáles son las condiciones sociales de que dependen y agruparemos después esas condiciones, según sus semejanzas y diferencias, en un cierto número de clases separadas, y entonces podremos tener la seguridad de que a cada una de estas clases habrá de corresponder un tipo determinado de suicidios. En una palabra, nuestra clasificación, en lugar de ser morfológica, será, a primera vista, etiológica. Esto no constituye una inferioridad, pues penetra mucho mejor la naturaleza de un fenómeno cuando se sabe su causa, que cuando se conocen sus caracteres, aún los más esenciales 27.

La búsqueda de las causas es idéntica a la búsqueda de las intenciones. Un texto es una combinación abierta a explicaciones múltiples y juicios particulares. Pero se tiende de forma irremediable a fijar una sola intención. El autor busca intenciones para fijar una lectura única.

A lo largo del siglo XIX el suicidio se considera como un problema social creciente. Se buscan sus posibles causas, analizando factores sociales y psicológicos. Pero el acuerdo general es creer que el aumento del índice de suicidios es debido al derrumbamiento progresivo del mundo tradicional. El suicidio de Durkheim se puede considerar como la depuración de esa amalgama de hipótesis que se van proponiendo. El estudio es una ratificación en tanto que argumentación comprobada con datos de las reglas metodológicas propuestas por el autor. El análisis de los suicidios permite realizar un análisis diferencial entre lo social y lo individual. Pero la dicotomía, desde el inicio de la obra, se va radicalizando hacia una negación del individualismo metodológico. Las explicaciones alternativas a los factores sociales se van rechazando de forma 
sistemática. El suicidio, un acontecimiento que tradicionalmente se había considerado objeto de estudio de la psicología, se convierte así en un hecho social.

Pero las intenciones de Durkheim son más ambiciosas. Estableciendo los hechos sociales como realidades externas al ser humano, los conceptualiza como realidades objetivas únicas. Los hechos sociales pasan a ser el objeto de estudio para analizar las áreas distintas de la sociedad. Su uso queda restringido a la sociología. Se afirma, pues, la sociología como ciencia. Una ciencia que es independiente de las otras, con un objeto de estudio propio y unas herramientas metodológicas determinadas. Durkheim presenta El suicidio como prueba del poder explicativo de la sociología, como una ciencia capaz de comprender la sociedad y de establecer sus leyes.

\section{Desintegración de lo social}

Durkheim considera que la naturaleza humana es bidimensional. Esto significa que el ser humano está formado por dos dimensiones que se manifiestan de manera simultánea: física y social. Los aspectos físicos se subordinan a los sociales.

En otros términos, si, como se ha dicho a menudo, el hombre es doble, es porque el hombre físico se sobreañade el hombre social. Ahora bien, éste último supone necesariamente una sociedad que lo exprese y que le sirva. Que llegue ella, al contrario, a disgregarse, que no le sintamos ya viviente y actuante alrededor y por encima de nosotros, y lo que en nosotros hay de social se encuentra desprovisto de todo fundamento objetivo. No es ya más que una combinación de imágenes ilusorias, una fantasmagoría que un poco de reflexión basta para desvanecer; nada, por consiguiente, que pueda servir de fin a nuestros actos. Y, sin embargo, este hombre social es el todo del hombre civilizado; es el que da precio a la existencia ${ }^{28}$.

La satisfacción de las necesidades corpóreas no es suficiente para el ser humano, pues existen otras de tipo ético. La vida en sociedad provoca en las personas la adquisición de valores en base a los cuales se toman las decisiones y desarrollan su comportamiento. Esta existencia que tiene lugar en la sociedad genera en los seres humanos una necesidad de contacto, un estímulo que los encamina hacia la comunicación. Ellos se asocian para conseguir superar los peligros reales o imaginarios que se presentan cuando se sienten desamparados, desprotegidos, solos ante el medio adverso.

En ocasiones la cooperación no funciona. Es el propio entorno social del individuo el que produce angustia, miedo a la existencia e incluso a la pérdida de la vida. La competencia entre los seres humanos del mismo grupo genera un proceso de aislamiento y ruptura del contacto con el cuerpo social. Puede incluso ocasionar el resquebrajamiento y la descomposición de la sociedad. La 
separación de los seres humanos lleva a la muerte social, pues la unión entre ellos es meramente accidental. Esto a su vez provoca la pérdida de la auténtica naturaleza del ser humano, que se halla inmerso en un proceso que él (o ella) mismo inicia, pero que no sabe detener. El paso de la angustia vital que se diluye en la sociedad recae luego sobre cada persona. Cuando el ser humano indefenso se siente enfermar, y busca la cooperación en el grupo social, no encuentra más que una multitud desconocida, sintiéndose solo. La sociedad se muestra ante él como una apariencia. Esta ilusión, que no puede llegar a alcanzar jamás, le desespera. La necesidad social que la propia naturaleza crea en las personas no se satisface.

Al reflexionar sobre su entorno, y el medio social que le es propio, el ser humano se puede sentir frustrado, pues piensa que el fin hacia el cual debe tender no existe. Este ser humano, que no se ha realizado como tal, aun estando en vida se siente morir. Se rinde agotado tras librar una lucha estéril al intentar defenderse del sufrimiento que le provoca vivir sin sentido. El acercamiento a la corporeidad le permite luego llegar a conocer sus tendencias emocionales. Se encuentra consigo mismo y se integra de nuevo. Genera un cuerpo social nuevo de acuerdo con la naturaleza que le es propia y que ahora ya conoce.

\section{Regularidad del suicidio}

La sociología que plantea Durkheim es la consecuencia de una ruptura con las creencias y principios psicológicos de su época. Durkheim anuncia en la introducción: «No vamos a investigar de momento en qué medida y bajo qué condiciones sea legítimo estudiar en esta forma [psicológica] los suicidios, pero es un hecho cierto que pueden ser considerados en un aspecto distinto [sociológico]» 29 . El análisis distinto durkheimiano considera que los comportamientos de las personas reproducen leyes y procesos sociales globales. El suicidio es casi un pretexto para estudiar la sociedad y sus regularidades. Es un fenómeno social que provoca la supervivencia de unos y unas y supone la muerte de otros y otras. Es el precio que pagan las personas por vivir en sociedad.

Durkheim presenta calendarios de suicidios sociales para los países europeos. Explica las tendencias comparando las tasas de suicidios en esos países durante el mismo tiempo ${ }^{30}$. Desprecia las categorías de tipo individual para ofrecer categorías temporales de tipo social e histórico. Durkheim plantea que la civilización se puede diferenciar en estadios, y su intención es buscar constantes que permitan comprar sociedades. Demuestra que en el proceso de civilización predominan factores sociales que controlan la vida cotidiana ${ }^{31}$. El comportamiento humano se analiza como un proceso largo que se explica por

\section{El suicidio, p. 8.}

30. En la mayoría de los cuadros no aparece España.

31. Durkheim descubre que la sociedad con sus normas y reglas tiene una existencia propia independiente de las personas. El suicidio para Durkheim es una regla social que ayuda a construir la sociedad. A través de su estudio se puede comprender el proceso de civilización. 
impulsos y revoluciones culturales. La racionalidad del suicidio egoísta, altruista o anómico viene impuesta por tales revoluciones. Se explica la sociedad en términos de "movimientos en onda» (en cierto sentido son movimientos predecibles) que se detienen y se ponen en marcha influenciados por procesos (hechos sociales) cuantificables y medibles.

Sorprende comprobar su construcción metodológica y empírica. Supone un ideario que crea escuela. Durkheim es consciente de que El suicidio le inmortaliza. Demuestra que la sociedad existe, pero partiendo de datos empíricos, desestimando abstracciones filosófica. Su método se centra en contrastar datos en años diversos, creando categorías nuevas. Ofrece tasas y coeficientes de prevención. Es el primer estudio metodológicamente cuantitativo que analiza socialmente eventos históricos. Surge así la dimensión moderna del estudio empírico. Es el primero plenamente sociológico que utiliza el porcentaje y la media sistemáticamente para validar hipótesis sociológicas. Crea una metodología basada en la representatividad, la consistencia y el incremento/decremento de indicadores objetivos. Durkheim es una referencia obligada para comprender los desarrollos de ideas y escuelas sociológicas posteriores ${ }^{32}$.

Utiliza datos que, a pesar de las incorrecciones de las fuentes censales de la época, muestran regularidades que son ciertas. Los cuadros y secuencias numéricas convierten a Durkheim en un maestro de la sistematización y validación de hipótesis. El suicidio considera metodológicamente la existencia de una estructura, de una conciencia colectiva, describiendo un proceso histórico que Durkheim se encarga de racionalizar e interpretar ${ }^{33}$. Los misterios de la personalidad y el comportamiento de las personas se explican a partir de esas secuencias. Las personas devienen flujos sociales, que se mueven con un cierto ritmo, y que se coordinan entre sí.

El suicidio sigue criterios más regulares — son pues más sociales- que otros indicadores soiodemográficos ${ }^{34}$. La tabla 1 - que se reproduce de la edición española original de El suicidio- presenta las variables de edad y género de la población del Sena y sus provincias ${ }^{35}$. Presenta los suicidios de cada grupo de edad según el estado civil calculando coeficientes de preservación con relación a los solteros. Se demuestra que la tendencia al suicidio de los viudos y de las viudas, se relaciona con la tendencia al suicidio en estado matrimonial y soltería. Se observa que a todas las edades los varones se suicidan más que las mujeres, incrementándose las muertes por suicidio en edades avanzadas. Se suicidan más los solteros seguidos de los viudos y los casados, con la excepción de los

32. Durkheim es un clásico esencial para comprender el desarrollo de un siglo de sociología. Desde Talcott Parsons a Norbert Elias, el enfoque durkheimiano se basa en las teorías de análisis de la estructura social, así como en los enfoques metodológicos de moda como el análisis de contenido histórico y los estudios comparativos.

33. Compara secuencias de cincuenta años como máximo.

34. Ya en la introducción Durkheim llama la atención sobre el hecho de que El suicidio sigue criterios más regulares que las defunciones. Es más fácil predecir el número de muertes por suicidio en un país que las defunciones totales.

35. El suicidio, p. 196. 
Tabla 1. Comparación de las cifras de suicidios por millón de habitantes, de cada grupo de edad y de estado civil, en el Sena y en provincias (1889-1891).

\section{Edad de las personas} que se suicidan en provincias

\begin{tabular}{lccc}
\hline Hombres & Solteros & Casados & Viudos \\
$15-20$ & 100 & 400 & - \\
$20-25$ & 214 & 95 & 153 \\
$25-30$ & 365 & 103 & 373 \\
$30-40$ & 590 & 202 & 511 \\
$40-50$ & 976 & 295 & 633 \\
$50-60$ & 1.445 & 470 & 852 \\
$60-70$ & 1.790 & 582 & 1.047 \\
$70-80$ & 2.000 & 664 & 1.252 \\
$>80$ & 1.458 & 762 & 1.129 \\
\multicolumn{5}{c}{ Promedios de coeficientes de preservación: }
\end{tabular}

$\begin{array}{lccc}\text { Mujeres } & \text { Solteras } & \text { Casadas } & \text { Viudas } \\ 15-20 & 67 & 36 & 375 \\ 20-25 & 95 & 52 & 76 \\ 25-30 & 122 & 64 & 156 \\ 30-40 & 101 & 74 & 174 \\ 40-50 & 147 & 95 & 149 \\ 50-60 & 178 & 136 & 174 \\ 60-70 & 163 & 142 & 221 \\ 70-80 & 200 & 191 & 233 \\ >80 & 160 & 108 & 221\end{array}$

Promedios de coeficientes de preservación:
Coeficientes de preservación con relación a las personas solteras

De casados De viudos

$\begin{array}{ll}0,25 & - \\ 2,25 & 1,39 \\ 3,54 & 0,97 \\ 2,92 & 1,15 \\ 3,30 & 1,54 \\ 3,07 & 1,69 \\ 3,07 & 1,70 \\ 3,01 & 1,59 \\ 1,91 & 1,29 \\ 2,85 & 1,45\end{array}$

De casadas De viudas

$\begin{array}{ll}1,86 & 0,17 \\ 1,82 & 1,25 \\ 1,90 & 0,78 \\ 1,36 & 0,58 \\ 1,54 & 0,98 \\ 1,30 & 1,02 \\ 1,14 & 0,73 \\ 1,04 & 0,85 \\ 1,48 & 0,72 \\ 1,49 & 0,78\end{array}$

En el Sena

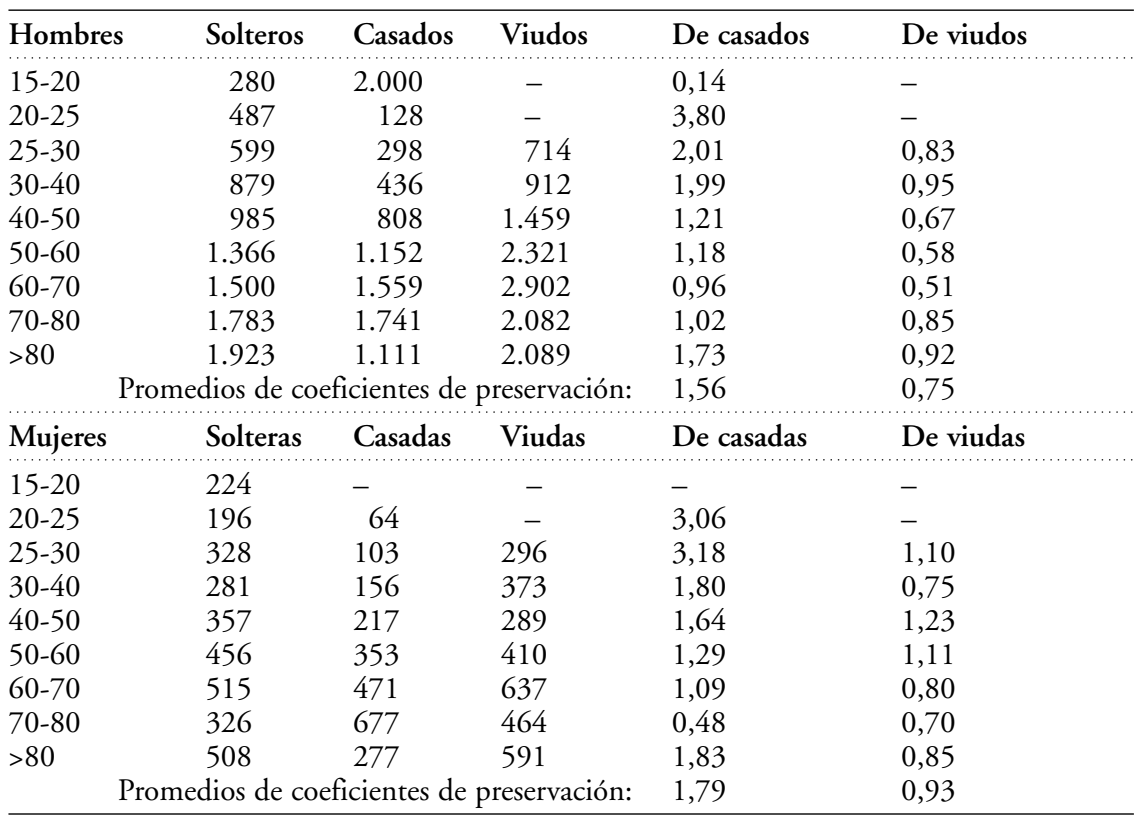


varones casados a edades entre quince y veinte años, que se suicidan más que los solteros. Observa que los viudos de edades de entre veinticinco y treinta años se suicidan más que los solteros y los casados. El coeficiente de preservación entre los casados es mayor que entre los viudos. Las personas a edades tempranas y con vida familiar tienen menos probabilidad de suicidio. Sucede lo mismo entre las mujeres. Las viudas mueren más que las solteras y que las casadas. A excepción de las mujeres de edades entre veinte y veinticinco años, el resto de edades presenta una secuencia de suicidios similar a los varones.

Durkheim descubre que el suicidio sigue criterios más regulares que las defunciones, que en los países protestantes mueren más personas que en los católicos, y que en tiempos de guerra y revolución las personas se suicidan menos. La vida social supone que un número de personas en función de su estado civil, género y religión se autoeliminen. La tabla 1 muestra que se producen más muertes entre viudos y viudas y solteros y solteras que entre casados y casadas. Existe un hecho externo que condiciona los comportamientos individuales. La familia previene de la regularidad de la muerte; sobre todo previene a las mujeres, que llevan una vida más familiar. Durkheim define «la sociedad» como categoría sociológica. Estudia así, en detalle, lo micro y lo personal en base a comparaciones de indicadores objetivos.

\section{La mujer, costilla o columna}

Durkheim es a veces punzante con párrafos como el siguiente:

He aquí, por fin, por qué puede la mujer, más fácilmente que el hombre, vivir aislada. Cuando se ve a la viuda soportar su condición mucho mejor que el viudo y buscar el matrimonio con menor pasión, se llega a creer que esta aptitud para prescindir de la familia es una señal de superioridad; se dice que, siendo muy intensas las facultades afectivas de la mujer, encuentra más fácilmente su empleo fuera del círculo doméstico, mientras que su abnegación nos es indispensable para ayudar a soportar la vida. En realidad, si tiene ese privilegio, es porque su sensibilidad es más bien rudimentaria que muy desarrollada. Como vive más que el hombre fuera de la vida común, la vida común la penetra menos; la sociedad le es menos necesaria, porque está menos impregnada de sociabilidad. Tiene pocas necesidades que se dirijan en ese sentido y las satisface a poca costa. Con algunas prácticas de devoción, algunos animales que cuidar, la solterona llena su vida. Si continúa tan fácilmente ligada a las tradiciones religiosas y si, por consecuencia, encuentra en ellas un útil abrigo contra el suicidio, es que esas formas sociales muy sencillas, bastan a todas sus exigencias. El hombre, por el contrario, las encuentra muy restringidas. Su pensamiento y su actividad, a medida que se desarrollan, desbordan cada vez esos marcos arcaicos. Pero entonces le hacen falta otros. Porque él es un ser social más complejo, no puede mantenerse en equilibrio si no encuentra fuera más puntos de apoyo, y porque su asiento moral depende de más condiciones, se altera también más fácilmente ${ }^{36}$. 
En muchos países las mujeres casadas apenas se suicidan, antes matan a sus maridos: muerto el perro se acabó la rabia. Por eso soportan mejor la viudedad y no vuelven a buscar el matrimonio con la pasión con que lo hacen sus colegas viudos. Con la pensión de viudedad que les proporciona el Estado, sustituyen la compañía del cónyuge por la de animales de compañía, o asistencia a la iglesia. De camino al confesionario aprovechan para realizar sus necesidades de sociabilidad charlando con alguna amistad. Para los coetáneos de Durkheim en esto consiste la sensibilidad rudimentaria que confiere a la mujer esa virtud mágica que representa su capacidad de aislamiento. Es mágica pues la protege del suicidio. La mujer no se suicida porque al no participar en la sociedad, ésta no la destruye.

¿No es la exclusión de la sociedad lo que lleva a algunas personas al suicidio? ¿No es así como explica Durkheim el mayor número de suicidios entre los solteros que entre los casados? Esa misma sociedad que según su estado de ánimo decide el número de sacrificios que requiere para perpetuarse, resulta ser un antídoto eficaz contra ese tipo de acción. La mujer, al no estar protegida por la sociedad, dado que no participa de ella, debería contribuir en gran medida a rellenar ese cupo de sacrificios que reclama la sociedad. Sin embargo, los números contradicen esta hipótesis y así el sociólogo requiere una explicación cuasi mágica para continuar construyendo su rompecabezas: la sensibilidad rudimentaria femenina. Es ese comodín con ovarios el que inmuniza a las mujeres ante el suicidio, de la misma manera que la pobreza protege a los pobres. La explicación de la inmunidad femenina resulta poco convincente tras el esfuerzo realizado en demostrar las causas sociales del suicidio. Durkheim es un genio que inventa la sociedad; a estas alturas nadie va a negarlo. Pero ese genio (individuo) forma parte de una sociedad, con una moral que también le penetra y supera. Empapado por ella no puede dejar de quedar reflejado en su texto, a través de los valores y creencias de la época. La causa del menor número de suicidios entre las mujeres no radica en la inmunidad que les proporciona su exclusión de la sociedad, más bien resulta ser su forma de vertebrar la sociedad (familia) lo que las protege. Quizás la explicación sea otra causa en que nadie ha reparado todavía.

\section{Nueva idea de sociedad}

Durkheim plantea en el texto que en una estructura social se establecen relaciones causales en torno al suicidio, que permiten establecer categorías de análisis. Se articula la inclinación del individuo en relación con el grupo social y éste a su vez con la colectividad.

No es una metáfora decir que cada sociedad humana tiene para el suicidio una aptitud más o menos pronunciada; la expresión se funda en la naturaleza de las cosas. Cada grupo social tiene realmente por este acto una inclinación colectiva que le es propia y de la que proceden las inclinaciones individuales; de ningún modo nace de éstas. Lo que la constituye son esas corrientes de ego- 
ísmo, de altruismo y de anomia que influyen en la sociedad examinada con las tendencias a la melancolía lánguida o al renunciamiento colectivo o al cansancio exasperado, que son sus consecuencias. Son esas tendencias de la colectividad las que, penetrando en los individuos, los impulsan a matarse. En cuanto a los acontecimientos privados, que pasan generalmente por ser las causas próximas del suicidio, no tienen otra acción que la que les prestan las disposiciones morales de la víctima, eco del estado moral de la sociedad. Para explicarse su despego de la existencia, el individuo se basa en las circunstancias que le envuelven más inmediatamente; encuentra la vida triste porque él es triste. Sin duda, en cierto sentido, su tristeza le viene de fuera, pero no de tal o cual incidente de su carrera, sino del grupo de que forma parte. He aquí porque no hay nada que no puede servir de causa ocasional al suicidio. Todo depende de la intensidad con que las causas suicidógenas han actuado sobre el individuo ${ }^{37}$.

En términos teóricos el autor propone el concepto de «sociedad» como una institución ${ }^{38}$ que regula por naturaleza a los fenómenos observados, o bien, como Durkheim llama «los hechos sociales». Es una reflexión que surge unos años después y que se contrapone a esa propuesta causal. Proviene de la aportación freudiana que identifica al ser humano como el eje en torno al cual se originan los fenómenos observables en la cultura. De ahí que las reflexiones teóricas expuestas por Freud unos años después tomen como referente histórico ejemplos de la mitología griega al tratar de identificar la universalidad de la estructura de los procesos psíquicos con el surgimiento de la civilización.

En la actualidad, o sea cien años después de la propuesta de Durkheim, el argumento incluye enfoques diversos dentro del campo social. Unos suponen la propuesta de interpretación estrictamente social y los otros, individual; ambos bajo la óptica del quehacer científico. Una reflexión derivada de lo anterior se encuentra en la dialéctica de los conceptos «sociedad» e «individuo». Para cada concepto, esta dialéctica sustenta un referente filosófico en contradicción constante; de ahí la dificultad para proponer una categoría que integre ambos conceptos. Aunque si ésta fuera una categoría teórico-metodológica estaría sometida a discusiones epistemológicas no resueltas. Si esta categoría existiera desde enfoques diversos, el estudio de los fenómenos sociales e individuales sería de mayor profundidad interpretativa.

La relación causal que a nivel empírico identifica Durkheim supone que el peso de la sociedad como institución que articula y diferencia a los seres humanos tiene vigencia. Pero la naturaleza individual sigue siendo un punto paradigmático que genera interpretaciones diversas. La «sociedad» como concepto teórico-analítico, podría ser la respuesta única que Durkheim tiene a nivel racional para establecer una relación causal entre los hechos sociales, y lo concreto que él observa. 


\section{Moral y conciencia colectiva}

Para Durkheim la sociedad supera al ser humano. El contexto social, exterior a la persona, es condición previa a la misma existencia de la moral. La sociedad es quien trasmite la autoridad necesaria a la hora de impartir las reglas morales, estando compuesta por los elementos supraindividuales de la vida social.

Es, pues, un error fundamental el confundir, como se ha hecho tantas veces, el tipo colectivo de una sociedad con el tipo medio de los individuos que la componen. El hombre medio es de una moralidad muy mediocre. Las máximas más esenciales de la ética sólo están grabadas en él con escasa fuerza, y aún están lejos de revestir la precisión y la autoridad que tienen en el tipo colectivo, es decir, en el conjunto de la sociedad. Esta confusión, que Quetelet precisamente ha cometido, hace de la génesis de la moral un problema incomprensible. Porque, puesto que el individuo es, en general, de tal mediocridad, ¿cómo ha podido constituirse una moral que le sobrepasa en tal punto, si no expresa mas que el promedio de los temperamentos individuales? Lo más no podría, sin un milagro, nacer de lo menos. Si la conciencia común no es otra cosa que la conciencia más general, no puede elevarse por encima del nivel vulgar. Pero entonces, ¿̨de dónde vienen esos preceptos elevados y netamente imperativos que la sociedad se esfuerza en inculcar a sus hijos y cuyo respeto impone a sus miembros. No sin razón, las religiones, y, siguiendo sus pasos, tantas filosofías, consideran que la moral no puede tener toda su realidad más que en Dios. Es que el pálido e incompleto esbozo que de ella contienen las conciencias individuales no puede ser considerado como el tipo original. Hace más bien el efecto de una reproducción infiel y grosera, cuyo modelo, desde luego, debe existir en alguna parte de los individuos. Por eso, la imaginación popular, con su simplismo ordinario, lo realiza en Dios. La ciencia, sin duda, no podría detenerse en esta concepción, que ni siquiera ha de conocer ${ }^{39}$. Sólo que si se la separa, no queda ya otra alternativa que la de dejar a la moral en el aire e inexplicada, o la de hacer de ella un sistema de estados colectivos. $\mathrm{O}$ no procede de nada que esté en el mundo de la experiencia o procede de la sociedad. No puede existir mas que en una conciencia; si no es en la del individuo, será en la del grupo. Pero entonces es preciso admitir que la segunda, lejos de confundirse con la conciencia media, la desborda por todas partes ${ }^{40}$.

De lo anterior se comprende que la sociedad a la vez que sobrepasa al ser humano forma también parte de él, de manera que los valores que conforman el sentir social configuran su misma personalidad.

El calificativo "moral» no viene dado a un acto en el que su fin sea algún interés individual. Ni la persona ni el resto de la población son un fin con

39. Nota a pie de página de Durkheim: «Del mismo modo que la ciencia de la física no tiene que discutir la creencia en Dios, creador del mundo físico, la conciencia de la moral no tiene que conocer la doctrina que ve en Dios el creador de la moral. La cuestión no es de nuestra incumbencia; no tenemos por qué pronunciarnos por ninguna solución. Las causas segundas son las únicas de que hemos de ocuparnos». El suicidio, p. 349.

40. El suicidio, p. 348-349. 
carácter moral en sí. De forma que la moral solamente puede tener como objetivo a la sociedad o grupo plural de personas asociadas. Si bien el carácter de esa sociedad es distinto al de los caracteres que a modo individual la generan. La idea de moral de Durkheim encierra dos aspectos clave: disciplina e ideal colectivo. Relaciona estrechamente religión y moral, contemplándolas como instrumentos de disciplina social. Las reglas religiosas, obligatorias, suponen la obediencia del ser humano al sentir moral de su sociedad. En cierta manera, considera la religión como social. Indica que mientras las religiones ubican la moral en Dios, la ciencia debe dedicarse al mundo de las apariencias.

La conciencia común es la fuente que imparte un carácter determinado a la sociedad. Es un sistema de creencias y sentimientos compartidos por todas las personas integrantes de la sociedad, definiendo el conjunto de relaciones que se establecen en su seno. Existen unos valores comunes a las personas miembros de todo sistema social que dan lugar a esa conciencia común. Durkheim se pregunta sobre la procedencia de la moralidad y la conciencia colectiva, indicando que no puede ser fruto de una tendencia general. La tendencia de la colectividad penetra en los seres humanos interfiriendo en sus modos de actuar. Cada persona está sometida a una realidad que la desborda, que es la realidad colectiva. En esa realidad colectiva se encuentra la conciencia común o de grupo que supera a la conciencia individual, y que se distancia de la conciencia media de las personas que conforman dicha colectividad. La conciencia colectiva dirige los destinos de las personas que integran la sociedad, imbuyendo normas morales a cada uno de ellas. Es por eso que dicha conciencia es diferente a la simple conciencia media de los seres humanos.

\section{Relaciones amor-odio}

Matarse parece ser la única alternativa. Pero acabar con un ser humano supone acabar con la sociedad, al menos simbólicamente. Individuo y sociedad mantienen una relación en que el odio y el amor son casi inseparables. Uno vive en la otra. Durkheim analiza varios componentes de esa relación.

La observación confirma, pues, la hipótesis. De una parte, la regularidad de los datos estadísticos implica que existen tendencias colectivas, exteriores a los seres humanos; de otra, en un número considerable de casos importantes podemos directamente comprobar esta exterioridad. Ella no tiene, por otra parte, nada de sorprendente para cualquiera que haya reconocido la heterogeneidad de los estados individuales y de los estados sociales. En efecto, por definición, los segundos no pueden venirnos a cada uno más que de fuera, puesto que no se derivan de nuestras predisposiciones personales; se forman de elementos que nos son extraños, expresan algo que no está en nosotros mismos. Sin duda, en la medida en que sólo éramos un todo con el grupo y vivíamos de su vida, estamos abiertos a su influencia; pero inversamente, en tanto que tenemos una personalidad distinta de la suya, le somos refractarios y tratamos de escaparle. 
Y como no hay nada que no lleve concurrentemente esta doble existencia, cada uno de nosotros está animado a la vez de un doble movimiento. Nos hallamos arrastrados en el sentido social y tendemos a seguir la inclinación de nuestra naturaleza ${ }^{41}$.

Es así como la sociedad resulta objeto de estudio de una disciplina naciente, la sociología. Se vuelve a los clásicos para no olvidarlos, para no perderse como ciencia. La sociología de Dukheim se basa en una premisa importante: para entender al ser humano es necesario conocer previamente a la sociedad, puesto que según es ella así es el ser humano. La sociedad es unidad, regulación y fuente de expresión.

La sociedad no es un simple conglomerado de personas, aunque no podría ser nada sin éstas. La sociedad es una organización, un sistema de relaciones más o menos definido y permanente. Algunos pensadores anteriores conciben a la sociedad como un todo: Aristóteles, Spencer o Rousseau. Estudiar la naturaleza de tal unidad y la cohesión social es para Durkheim el problema inicial de la sociología. Considera que la sociedad es para Durkheim el problema inicial de la sociología. Considera que la sociedad de su tiempo atraviesa la mayor crisis moral de la historia. Llega a la convicción de que es indispensable una respuesta al problema de la cohesión para comprender la naturaleza de la organización en las sociedades contemporáneas. Para analizar un fenómeno tan subjetivo aplica un método propio de la sociología basado en los índices objetivos. Se pueden descubrir dos principios fundamentales de la unidad social, estructura social en donde el ser humano está absorbido por el grupo; y otro apoyado en la interdependencia mutua y funcional, que crea una estructura en donde la personalidad individual acaba siendo proclamada como sagrada.

La sociedad es además un sistema de orden, un régimen de disciplina. Se incluye, así, un aspecto regulador, tanto sobre el complejo de normas como sobre los mecanismos que obligan al cumplimiento de esas normas. La vida social es vida nómica, es decir, perteneciente a normas o leyes. La sociedad es un estado de nomía. La antítesis de la vida social, su única alternativa, como Hobbes percibe, es una situación sin ley, la ausencia de toda norma, el estado de naturaleza. Al hablar de la sociedad se debe pues hablar de control. El orden social es disciplinario y limitador. Durkheim da importancia a estas funciones reguladoras de la sociedad. Le sirven para convencer de la posibilidad de una ciencia positiva de la sociología. Puede usarlo como índice de datos objetivos y perceptibles sin dificultad. Gracias a esa característica externa, lo social se convierte en instrumento de identificación.

La consecuencia psicológica de la nomía social es la frustración individual. Los impulsos se encuentran retraídos cuando el ser humano vive en una sociedad ordenada. El precio que se paga por tener esas normas necesarias para vivir en comunidad es la represión del ser humano. Pero si la sociedad es constreñimiento, es también expresión; es restricción pero al mismo tiempo libera- 
ción. Es como el dios Jano, una cabeza con dos caras, o, mejor aún, con dos expresiones distintas de un sólo dios. La sociedad es fuente de ideas y valores. Los fenómenos sociales son esencialmente sistemas de valores e ideales. Una sociología que pretenda ser completa tiene que esforzarse por ver cómo la sociedad orienta a la vida humana y contribuye al desarrollo de la personalidad. El ser humano es un ser dual, con una herencia doble: la naturaleza originaria y la social. En esa fuente dual está el origen de su inquietud. Esta tensión es un precio gravoso con el que pagar la vida social, pero necesario si se quiere vivir como otras personas. De la sociedad y no de la naturaleza es de donde se reciben las condiciones necesarias para el desarrollo de la personalidad. No hay fórmula para describir un fenómeno tan complejo como es la sociedad. Las tres palabras son insuficientes. Durkheim descubre el objeto de estudio de la sociología: la sociedad como unidad, regulación y expresión.

\section{La criminal}

Durkheim insiste en el alejamiento de la vida social por parte de la mujer. La preserva así del suicidio y del homicidio. Durkheim muestra la ideología de la época donde los círculos intelectuales están dominados por varones. El texto refleja el peso de las actitudes patriarcales hacia las mujeres en la sociedad y las tópicas acusaciones criminales contra las mujeres.

Por lo pronto está la influencia parecida que el sexo ejerce sobre el suicidio y el homicidio. Para hablar con exactitud esta influencia del sexo es mucho más un efecto de causas sociales que de causas orgánicas. No es porque la mujer difiere fisiológicamente del hombre por lo que se mata menos o por lo que se mata más; es que ella no participa del mismo modo en la vida colectiva. Pero, además, es preciso que la mujer tenga ese mismo alejamiento para esas dos formas de inmoralidad. Se olvida, en efecto, que hay crímenes de los que ella tiene el monopolio; son los infanticidios, los abortos y los envenenamientos. Siempre que el homicidio está a su alcance, le comete con tanta o mayor frecuencia que el hombre. Según Octtingen $(1)^{42}$ le es imputable la mitad de los asesinatos domésticos. Nada autoriza, pues, a suponer que tenga, en virtud de su constitución congénita, un respeto grande para la existencia ajena; pero ocurre que le faltan las ocasiones, porque está menos fuertemente mezclada a la vida. Las causas que impulsan a los crímenes de sangre obran menos sobre ella que sobre el hombre, porque se mantiene más fuera de su esfera de influencia. Por esta misma razón está menos expuesta a las muertes por accidente; de cada 100 fallecimientos de este género, sólo 20 son femeninos» 43 .

Se trata del eterno mito de Eva que atribuye a las mujeres la culpa de todas las situaciones negativas. Carga sobre el mundo femenino la responsabilidad de las penas y dolores de este mundo. Es mejor mantenerla alejada de la vida 
colectiva. La dominación masculina no es un hecho natural en el sentido biológico; es social y se apoya en ciertas estrategias que le permiten materializarse.

Los actos inmorales cometidos por la mujer son efecto de causas sociales. Infanticidios, abortos y envenenamientos son los actos delictivos que se atribuyen con más frecuencia a las mujeres o, como afirma Durkheim, de los que la mujer tiene el monopolio. Durante muchos años en vez de considerar las causas que pueden llevar a una mujer a cometer infanticidio, debido a la desesperación y el pánico, más bien se considera como un crimen atroz contra el fruto de sus entrañas. El infanticidio y el aborto preocupan por representar una desviación de la maternidad que es vista como ejercicio articulado a los discursos ideológicos dominantes y con sus variaciones a través del tiempo. Las mujeres, debido a su capacidad reproductora, son vistas como más próximas a la naturaleza y asociadas a menudo a la brujería. Son consideradas como fuente de desorden potencial, que han de ser controladas. Como responsable del espacio familiar la mujer es a menudo sospechosa de crímenes domésticos, de brujería e incluso de envenenamiento. La integración de la mujer en la sociedad debe ser reducida y controlada, en favor de la cohesión social.

Durkheim no es el único autor que está de acuerdo con el alejamiento de la mujer de la vida social. Tres décadas después Freud en El malestar de la cultura considera que la mujer no sólo no colabora en la tarea de la civilización — cuyo logro juzga casi exclusivamente masculino—, sino que además entorpece esa tarea. Las ideas de Freud sobre la psicología femenina dimanan del supuesto básico de que la función típica de la mujer en la vida estriba en permanecer en casa, mostrarse pasiva en relación con el varón, procrear y cuidar de los hijos e hijas. Estas actitudes, que no son más que el reflejo de la sociedad de su tiempo, obstaculizan el desarrollo de la mujer precisamente en un momento en que su dependencia social y económica está seriamente amenazada. Las mujeres exigen entonces su derecho a aprender y trabajar, así como la participación en un sistema capitalista que los varones consideran como prerrogativa masculina. Es otro ejemplo de como la sociedad - y la sociología— se transforman en un siglo.

\section{Más allá del bien y del mal}

El azar puede suponer ignorancia de la causalidad. Barrington Moore (1978) señala dos razones para que el pensamiento humano dirija su reflexión preferentemente hacia la temática del $\mathrm{mal}^{44}$. El mal es algo que suscita una oposición, que transciende con las palabras o con los hechos, mientras que el bien parece colmarse a sí mismo sin necesidad de otra trascendencia. La felicidad acontece con más variedad, matices y sutilezas que la desgracia, o al menos

44. Barrington MoOre (1978). Injustice: The Social Bases of Obedience and Revolt. Nueva York: White Plains, p. 294. 
resulta más fácil convenirlo así. El lenguaje del mal resulta más unívoco, consciente o explícito.

La problemática del mal es monopolizada en un principio por el lenguaje de la religión. El cristianismo utiliza dialécticas sucesivas para superarlo: pecado y castigo, pasión y resurrección, misterio y salvación. Aun reconociendo la Providencia o voluntad divinas en la permisión de los males, fueran naturales o sociales, así como el significado absoluto del misterio de la salvación, intenta una lucha humana contra el mal, de forma material y simbólicamente: milagros y plegarias, consuelos y caridades, rebeliones y ascetismos. El saber contra el mal, la ambigüedad de la especie o el conflicto social supone también una de las mayores controversias de la ilustración, tal y como aparecen en Rousseau y Voltaire. El mal, el desorden, el conflicto, así como el caos social o natural se justifican filosóficamente: para el orden teológico representa un bien ulterior que los mortales no alcanzan a comprender. Según el precepto panglossiano de Voltaire, se vive en el mejor de los mundos posibles. Rousseau no cree que las cosas sean de esta manera. Afirma que el mal, tal como realmente se vive incluso el más natural, se vive dolorosamente mucho más por su presentación y lectura social (soledad, indiferencia, temor, desprecio e incomprensión) que por su origen natural o divino.

En el siglo Xx las ciencias sociales son demasiado esclavas de cuestiones como el funcionamiento de los negocios, la sumisión de los pueblos o el gobierno de los Estados, por poner ejemplos conocidos. Todo esto llega incluso a eclipsar el pensamiento y las teorías básicas de las ciencias sociales: la racionalización de la problemática del mal en todas sus encarnaciones. La teoría del suicidio de Émile Durkheim no es ajena a esta discusión.

Ahora bien, no se conoce sociedad donde, bajo formas diferentes, no se observe una criminalidad más o menos desarrollada. No hay pueblo cuya moral no esté cotidianamente violada. Debemos, pues, decir que el crimen es necesario, que no puede dejar de existir, que las condiciones fundamentales de la organización social, tal como nos son conocidas, lo implican lógicamente. En consecuencia, es normal. Es vano invocar aquí las imperfecciones inevitables de la naturaleza humana y sostener que el mal, aunque no pueda ser impedido, no deja de ser el mal; éste es lenguaje de predicador, no de sabio. Una imperfección necesaria no es una enfermedad; de otro modo, habría que admitir la enfermedad en todas partes, puesto que la imperfección está en todas partes. No hay función del organismo, ni forma anatómica, a cuyo propósito no se pueda imaginar algún perfeccionamiento. Se ha dicho muchas veces que un óptico se avergonzaría de haber fabricado un instrumento de visión tan grosero como el ojo humano. Pero de ello no se ha deducido, ni se podrá deducir, que la estructura de este órgano sea anormal. Hay más: es imposible que lo que es necesario no tenga en sí alguna perfección, para emplear el lenguaje un poco teológico de nuestros adversarios. Lo que es condición indispensable de la vida no puede dejar de ser útil, a menos que la vida no sea útil ${ }^{45}$. 
La muerte es el revulsivo y al mismo tiempo el cimentador de la humanidad; de la humanidad como sociedad y cultura, como sistema, organización, conflicto, ritmo y cambio. La muerte individual (y colectiva) es también el fenómeno frente al cual se decide el sentido de la sociedad.

El sentido durkheimiano es, a diferencia del pensamiento anterior, inmanente y no trascendente. El suicidio es siempre ante alguien, ante la naturaleza, la sociedad, alguna persona, o ante uno mismo; y en última instancia ante la muerte. La muerte voluntaria ya no se ejecuta ante la divinidad, para aplacar sus iras, sino ante la sociedad (para aplacar otras iras). Se trata entonces de una sociedad sacralizada y de una religión que no es más que una hipóstasis de la misma sociedad. Los engranajes que hacen funcionar la maquinaria social tienen sus propias leyes, y el suicidio no es más que uno de ellos. En la sociedad los casos anormales o desviados cumplen la función de autorregular la marcha del conjunto de la sociedad. Las ventajas compensan los inconvenientes. El mal deviene así un mal menor, por no decir un bien.

\section{Progreso de la sociedad}

Uno de los hechos sociales observados es que existe una relación estrecha entre progreso e individualismo. En las sociedades actuales el ser humano tiene que enfrentarse constantemente a la idea de perfeccionamiento para tener cabida en una realidad social que tiende poco a poco a deshumanizar a la propia persona.

En las sociedades y en los medios donde la dignidad es el fin supremo de la conducta, el individuo se inclina fácilmente a considerar como a un dios al hombre contenido en él, a erigirse él mismo en objeto de su propio culto. Cuando la moral se aplica ante todo a darle una alta idea de sí mismo, bastan ciertas combinaciones de circunstancias que se haga incapaz de percibir nada que esté por encima de él. El individualismo, sin duda, no es necesariamente el egoísmo, pero se le acerca; no se puede estimular al uno sin extender más el otro. Así se produce el suicidio egoísta. En fin, en los pueblos en que el progreso es y debe ser rápido, las reglas que contienen a los seres humanos deben ser suficientemente flexibles y maleables; si ellas guardasen la rigidez inmutable que tienen en las sociedades primitivas; la evolución, trabada, no podría hacerse con bastante prontitud. Pero entonces sería inevitable que los deseos y las ambiciones, estando contenidos con menos fuerza, desbordasen sobre ciertos puntos tumultuosamente. Desde el momento en que se inculca a los hombres el precepto de que es para ellos un deber progresar; es más difícil hacer que se resignen y, por consecuencia, no puede dejar de aumentar el número de descontentos y los inquietos ${ }^{46}$.

La competencia entre las personas es cada vez mayor y poco a poco se abandonan las ideas de solidaridad y cooperación. Todo esto plantea un dilema en 
la relación entre el ser humano y la sociedad, en el sentido de que si la persona tiene un origen y un fin social es difícil enfrentarse a ese individualismo hacia el cual tienden las personas en la actualidad.

El problema del individualismo llevado a su extremo puede producir una inclinación al suicidio que tiene lugar como consecuencia de una ruptura racional de la persona con la sociedad. Este tipo de suicidio lo define Durkheim como "suicidio egoísta», que tiene lugar cuando el individuo se desliga de la sociedad. Es debido a un exceso de conciencia individual, con el consiguiente desamparo social propio del individualismo. Por otro lado, se puede considerar el individualismo opuesto a la tesis de Durkheim, en el sentido de que él afirma que las personas tienen una naturaleza social. Es la sociedad la que proporciona el sentido de solidaridad e inculca creencias religiosas, morales y políticas. El ser humano que se desliga de la sociedad se separa de la vida, faltándole por ello la razón para vivir, desesperándose y no encontrando sentido a su propia existencia. Una vez expuestas estas opiniones no es fácil enfrentarse a este debate y llegar a una solución definitiva. Quizás sería bueno optar por una solución intermedia, en el sentido de establecer un equilibrio entre la dimensión social e individual de las personas. Esta contradicción es quizás el tema más complejo y característico de las sociedades contemporáneas.

\section{Herencia de los clásicos}

Es demasiado osado pensar, como sugiere Durkheim en El suicidio, que los progresos anormales del suicidio y el malestar general que sufren las sociedades contemporáneas derivan todos de las mismas causas:

Una monografía sobre el suicidio tiene un alcance que traspasa el orden particular de los hechos con que especialmente se enlaza. Las cuestiones que suscita son solidarias de los más graves problemas prácticos que se plantean actualmente. Los progresos anormales del suicidio y el malestar general de que están atacadas las sociedades contemporáneas se derivan de las mismas causas. Lo que prueba el número excepcionalmente elevado de las muertes voluntarias, es el estado de perturbación profunda que sufren las comunidades civilizadas y atestigua su gravedad. Hasta se puede decir que nos da su medida. Cuando estos sufrimientos se expresan por boca de un teórico, se puede creer que son exagerados e infielmente traducidos. Pero aquí, en la estadística de los suicidios, vienen como a registrarse por sí mismos, sin dar lugar a la apreciación personal. No se puede, pues, contener esa corriente de tristeza colectiva, más que atenuando, a lo menos, la enfermedad general de que es el resultado y el signo. Hemos demostrado que, para alcanzar ese fin, no era necesario restaurar artificialmente formas sociales anticuadas y a las que no se podría comunicar más que una apariencia de vida, ni inventar por completo otras enteramente nuevas y sin analogías en la historia. Lo que se precisa es investigar en el pasado los gérmenes de vida nueva que contenía y apresurar su desarrollo ${ }^{47}$. 
Las relaciones de la sociedad con los hechos o fenómenos sociales son profundas y a veces siniestras. Para Durkheim las muertes voluntarias explican la sociedad contemporánea, su situación y sus desavenencias. Pero los suicidios no son traducciones literales del estado de las sociedades. La universalidad del suicidio rechaza la idea de que este fenómeno pueda ser generalizable a la hora de descubrir todas y cada una de las vicisitudes de esas sociedades.

Durkheim en El suicidio se adentra en la naturaleza de la sociedad y analiza uno de los efectos primarios del ser humano como es el Tánatos; pero se trata de un Tánatos social. Para Durkheim no cuentan tanto los seres humanos como la colectividad. El suicidio es un hecho personal (de una persona), pero puede interpretarse como un hecho social. Esta es la apuesta novedosa de Durkheim. Estudiando el fenómeno social del suicidio no se conocen todas las características de la sociedad, pero sí se pueden desvelar algunas de ellas. Con una intuición especial Durkheim estudia el suicidio porque es uno de los pocos hechos sociales que se encuentran a mitad de camino entre el ser humano y la colectividad. Una persona se suicida tanto para sí misma como para la sociedad.

Las muertes voluntarias, con su exceso, proporcionan una medida de la sociedad contemporánea. Pero quizás sea al revés y sean las sociedades las que ofrezcan la medida de los suicidios. De todas maneras, cada vez se participa más de un conocimiento multidisciplinario; las sociedades se miden con más índices, comparables o no. El suicidio es uno de esos índices con los que se puede medir una sociedad. Es un factor bueno, ya que en sí mismo agrega un número considerable de condicionantes tanto individuales como sociales. A la vez, es un indicador generalizable a todas las sociedades. Esa universalidad que propone Durkheim se confirma al observar un siglo más tarde que la sociedad sigue con las mismas enfermedades, conflictos y malestares de la civilización.

Freud tres décadas más tarde presenta igualmente una fotografía de la sociedad en que vive. Muestra una sociedad triste, enferma, dentro de una jaula de hierro repleta de preocupaciones históricas. Es la vieja Europa de hace un siglo, la Europa preocupada por el origen del hombre, y la Europa de las guerras. Es una fotografía movida de una época en crisis. Pero a la vez muestra un respiro de esperanza. Para Durkheim su metodología no miente, y sirve para entender la realidad presente y buscar una solución para el futuro. Durkheim se posiciona en el libro como sanador neófito de la sociedad. Pretende frenar el suicidio. La solución según Durkheim está en «investigar en el pasado los gérmenes de vida nueva que contenía y apresurar su desarrollo» ${ }^{48}$. El párrafo anterior refleja un Durkheim animoso, con ganas de restaurar y de hacer florecer en la sociedad todo aquello que no está ya marchito. Casi trata al suicidio como una enfermedad, y a la sociedad como un enfermo o una enferma a quien hay que curar. Pero al final del libro se puede corroborar la imagen de un Durkheim escéptico ante el suicidio. Todo lo anterior pasa por ser un libro de ciencia, un manuscrito de la phisica moderna, un estudio de sociología. Los 
datos corroboran un hecho social, una realidad. Durkheim crea así una obra al más puro etilo de los modernos científicos de su época.

Lo más interesante del libro de El suicidio es su metodología y su construcción. Se trata de un libro poco usual para su época. Casi se puede decir que es demasiado moderno. Marx, Weber, Simmel o Pareto no llegan a realizar un ejemplar así de "científico", moderno, actual, de fácil lectura; con contenidos entendibles, y con ideas nuevas y complejas. Durkheim, bajo una cierta capa de escepticismo, pretende al final curar a la sociedad de un mal: la falta de sociedad. Cien años más tarde es preciso recoger su metodología innovadora y reflexionar sobre sus ideas geniales. Eso es lo que hemos hecho para «conmemorar» este centenario.

\section{Bibliografía de Durkheim en castellano}

Marga Marí-Klose

Anna Nos

La obra de Émile Durkheim se empieza a traducir tempranamente en España, pero luego se interrumpe. El seguimiento de las publicaciones de las obras del sociólogo francés en España evidencia algo más que un mero listado de la compra. El autor de El suicidio propone una lectura sociológica de los datos estadísticos. La aplicación de esta idea resulta igualmente efectiva cuando se trata de analizar las fechas de publicación de las obras de Durkheim en España. Estas fechas no son puntos aislados e inconexos en una secuencia temporal. Adquieren significado cuando esbozan un cuadro realista de un detrminado momento histórico en nuestro país. Émile Durkheim pronto se empieza a traducir al castellano - como Simmel, como Freud-, pero la difusión de su obra queda truncada al poco tiempo. No es hasta los años ochenta y noventa del siglo XX que Durkheim se vuelva a editar, a comprar, a leer, a repensar. Las pàginas que siguen presentan una bibliografia comentada de las obras de Durkheim publicadas en lengua castellana. El criterio seguido en esta presentación es su fecha de publicación en España o Latinoamérica.

La presente bibligrafía recoge las obras de Émile Durkheim traducidas en lengua castellana desde la primera publicación hasta nuestros días, coincidiendo con el centenario del El suicidio. Las fuentes consultadas para su realización han sido fundamentalmente la Biblioteca de Cataluña y la Biblioteca de la Universidad de Barcelona. Además, se ha consultado el excelente análisis bibliográfico de los clásicos de la sociología en castellano realizado por el Seminario de Teoría Sociológica de la Universidad Autónoma de Barcelona publicado con el título «Bibliografía en español de los clásicos de la sociología» Papers, 15 (1981), p. 153-199.

Las reglas del método sociológico (1912). Madrid: Daniel Jorro, 256 p. [Es el trabajo metodológico principal de Durkheim, que apareció en 1895 seguido (en 1897) por su aplicación empírica de esos métodos en el esudio de El suicidio. En esta 
obra argumenta que la tarea especial de la sociología es el estudio de los hechos sociales. Las reglas resultan poco comprensibles si se leen sin tener presente que no son sino la exposición abstracta y formal de las dificultades metodológicas concretas con que Durkheim tropezó al elaborar La división del trabajo social. La primera edición en lengua castellana está traducida por Antonio Ferrer y Robert (abogado del Ilustre Colegio de Abogados de Barcelona). Incluye también una bibliografía comentada de Durkheim.]

Alemania por encima de todo: La mentalidad alemana y la guerra (1915). París: Librarie Armand Colin, 47 p. [Se trata de una traducción al castellano de Pedro Salinas de un folleto francés de 0,50 francos.]

Educación y sociología (1922). Madrid: Ediciones La Lectura, 192 p. [Traducción de Alice Pestaña. Edición original de 1922, póstuma. Se incluye una introducción (p. 10-53) de P.F.(?) quien realiza una exposición breve sobre la obra pedagógica de Durkheim y su estrecha relación con el conjunto de su obra sociológica. El libro recoge cuatro artículos publicados en Francia entre 1903 y 1911. Los dos primeros reproducen los artículos «Educación y pedagogía del nuevo Diccionario de pedagogía y de institución primaria», publicado bajo la dirección de F. Buisson (París, Hachette, 1911). El tercero es la lección de apertura de Durkheim cuando toma posesión de su cátedra en la Sorbona (1902). Apareció en la Revista de metafísica y de moral, número de enero de 1903. El último es la lección de apertura del curso organizado por los candidatos a las agregaciones de la enseñanza secundaria, impartida en noviembre de 1905; esta lección apareció en la Revista politica y literaria (Revista azul), número 20 de enero de 1906.]

El suicidio: Estudio de sociología (1928). Madrid: Editorial Reus, Biblioteca Jurídica de Autores Españoles y Extranjeros, vol. 127, 450 p. [Incluye un estudio preliminar del propio traductor, Mariano Ruiz-Funes (catedrático de Derecho Penal de la Universidad de Murcia), sobre "Etiología del suicidio en España», p. I-XXXIX, dedicado a Constancio Bernaldo de Quirós. La primera edición francesa. La primera edición en inglés no es hasta 1951. Hay, pues, un impacto bastante temprano de esta obra en España.]

La división del trabajo social (1928). Madrid: Daniel Jorro, 492 p. [En este texto Durkheim intenta reproducir, en un mismo gesto, la alternativa científica a los diagnósticos y programas socialistas y edificar la ciencia que posibilitaría tal alternativa. Además, se exploran las líneas fundamentales de lo que el sociólogo francés considera que es la sociedad moderna: su génesis, su inscripción en el proceso histórico, funcionamiento y defectos. Incluye el prefacio de la segunda edición, de 1902: "Algunas observaciones sobre las ocupaciones profesionales». Traducción de Carlos González Posada. Edición original de 1893.]

El socialismo (1931). Barcelona: Apolo, 395 p. [Es una selección de conferencias que Durkheim pronuncia sobre el socialismo entre 1895 y 1896. En ellas desarrolla y explora las implicaciones y la definición ya establecida y analiza los orígenes del socialismo a partir del siglo XVIII. Acentúa considerablemente las conexiones históricas entre socialismo y sociología. Incluye un breve prólogo de Francisco Cañadas (también traductor), p. 5-9. En estas cinco páginas el traductor realiza una declaración de principios de la sociología como ciencia y de Durkheim como la figura que encarna ese ideal científico. Cañadas invita a leer este libro a la luz de los momentos históricos (1931) «de confusión y efervescencia que viven en la conciencia de los pueblos modernos y los perturban con ansias creadoras». Edición original en francés de 1896.] 
El socialismo (1932). Barcelona: Apolo, 389 p. [En una España republicana, con un año de diferencia, aparece la segunda edición de este libro. Se trata de una copia exacta de la primera edición con el mismo prologuista (p. 7-11) y traductor.]

El socialismo (1934). Barcelona: Apolo, 389 p. [Tercera edición, idéntica copia de la anterior.]

Sociología: Las reglas del método sociológico (1961). Córdoba, Argentina: Assandri, 194 p. [Prólogo, versión revisada y anotaciones de Alfredo Poviña (p. 7-16). El libro reúne bajo el título Sociología, las reglas del método sociológico, y Sociología y ciencias sociales (éste último es una parte de la obra colectiva El método en ciencias sociales). Para Las reglas se utiliza la traducción española de Antonio Ferrer y Robert en la edición de Daniel Jorro, la que ha servico a posteriores ediciones latinoamericanas. Sobre esta traducción se realiza una revisión general con el fin de agregarle unas notas aclaratorias al texto, sobre la base del original francés según la quinta edición de Félix Alcan (París, 1910), idéntica a las anteriores. La segunda parte del presenta libro contiene un trabajo valioso de Durkheim titulado "Sociología y ciencias sociales» que forma parte de la obra colectiva El método en las ciencias sociales, publicada también por Alcan en 1928. La presente edición es exclusiva y no se tiene noticia de otra traducción al español.]

Las reglas del método sociológico (1964). Buenos Aires: Dédalo, 157 p. [Traducción de Antonio Ferrer en base a la décima edición francesa (Les régles de la mèthode sociologique, París: PUF, 1974).]

Pragmatismo y sociología (circa, 1965). Buenos Aires: Schapire, 157 p. [Traducción del francés de Noe Jitrik. Incluye un prefacio de Armand Cuvillier. Edición original, póstuma, de 1955. Se trata de la reconstrucción del curso que Durkheim imparte en la Sorbona en el curso académico 1913-1914 a partir del llamamiento realizado por su discípulo y sobrino Marcel Mauss. Este curso, del que por fortuna existe una versión publicada sacada de las notas de sus alumnos ${ }^{49}$, es para Mauss «la culminación de la obra filosófica de Durkheim».]

Las reglas del método sociológico (1965). Buenos Aires: Schapire, $111 \mathrm{p}$.

El suicidio: Estudio de sociología (1965). Buenos Aires: Schapire, 325 p. [Edición original de 1897. Se trata de una versión directa del francés traducida por Lucila Gibaja. Al final de su introducción, el propio Durkheim presenta una bibliografía general de la época sobre el tema del suicidio, así como una referencia a las estadísticas consultadas.]

Lecciones de sociología: Física de las costumbres y del derecho (1966). Buenos Aires: Schapire, 205 p. [Edición original, póstuma, en Estambul 1950. Corresponde a tres cursos universitarios impartidos en Burdeos, entre 1896 y 1899, sobre "Física general de la moral y del derecho».]

La división del trabajo social (1967). Buenos Aires: Schapire, 346 p. [Traducido del francés por David Maldavsky. Incluye un prefacio de Durkheim a la segunda edición «Algunas indicaciones sobre los grupos profesionales» (p. 7-32).]

Las formas elementales de la vida religiosa: El sistema totémico en Australia (1968). Buenos Aires: Schapire, 457 p. [Es un estudio de las creencias y prácticas religiosas de los aborígenes, clasificadas e interpretadas por Durkheim en virtud de su dicotomía

49. Sorprendentemente, los únicos análisis publicados de este trabajo son los de Cuvillier (1955 y 1958) y Gademar (1969). Merece ser mucho más conocido, tanto por lo que revela respecto al pensamiento de Durkheim como por su crítica de unas ideas que aún siguen en uso, bajo diversas formas. 
rígida y estática. Intenta explicarlas vinculando lo sagrado a la vida de la sociedad y lo profano a la vida del ser humano. La tesis que el autor postula es que «las cosas sagradas son simplemente ideales colectivos que se han fijado en objetos materiales» ${ }^{50}$. Traducción del francés de Iris Josefina. Edición original de 1912. En el ejemplar consultado en la Biblioteca de Cataluña faltan las once páginas iniciales.]

Las reglas del método sociológico (1970). Buenos Aires: La Pléyade, 199 p.

El suicidio: Estudio de sociología (1971). Buenos Aires: Schapire, 325 p. [Traducida del francés por Lucila Gibala. Se trata de la tercera edición.]

El socialismo (1972). Buenos Aires: Schapire, 134 p. [Se trata (como se menciona anteriormente) de un curso dictado en Burdeos en la Facultad de Letras de noviembre de 1895 a mayo de 1896 . Es la primera de una historia del socialismo redactada en forma de lecciones. La presente edición (traducida por Idea Vilariño) incluye un prefacio de Pierre Birnbaum en el que repasa la trayectoria de Durkheim por la «cuestión social» y lo sitúa en el pensamiento de su época. En este prefacio se hace especial mención a autores que, como Nisbet, Gouldner o Coser, consideran a Durkheim un autor conservador y tradicionalista, o, como lo califica Karl Manheim «positivista burgués». A través del análisis de diferentes obras de Durkheim, se afirma su adhesión a las nociones de consenso, integración y orden. El libro incluye una introducción a las lecciones durkheimianas redactada por Marcel Mauss francamente interesante. En ella su discípulo se refiere abiertamente al interés de Durkheim por marcar con claridad las diferencias que le separaban del (en el lenguaje de la época) "colectivismo», a fin de que cesen los rumores que obstaculizan en gran medida su ascenso en la jerarquía académica.]

La educación moral (Educación y sociología) (1973). Buenos Aires: Schapire, 310 p. [Traducido por Luis Liacho.]

Educación y sociología (1974). Buenos Aires: Schapire, 99 p. [Traducido por Idea Vilariño.] Lecciones de sociología: Física de las costumbres y del derecho (1974). Buenos Aires: La Pléyade, 82 p. [Traducción del original en francés por Estela Canto. Prólogo a la primera edición por Hüseyin Nail Kubali (decano de la Facultad de Derecho de Estambul). Este trabajo fue publicado por primera vez por la Facultad de Derecho de la Universidad de Estambul. Sus originales fueron hallados por un estudioso turco que realizaba su tesis doctoral sobre La idea de estado en los precursores de la escuela sociológica francesa, y revisaba los papeles de Durkheim depositados en el Museo del Hombre, en París. Es publicado por primera vez en francés en 1950, y constituye una novedad para los lectores de habla española. Es un tratado excelente en el que se analizan las diversas concepciones de Estado en las escuelas sociológicas, así como los constituyentes esenciales de la institución. Georges Davy hace una introducción (p. 11-42) donde precisa brevemente cuáles son los temas mayores de la doctrina y los preceptos esenciales del método del fundador de la sociología francesa.]

Lecciones de sociología: Física de las costumbres y el derecho (1974). Buenos Aires: Schapire, 205 p. [Traducción del francés por David Maldavsky.]

Las reglas del método sociológico (1974). Madrid: Morata, 149 p. [Versión española de L.E. Echevarría Rivera (abogado diplomado por la Universidad de Cambridge). Se trata de una primera edición sobre la decimoctava francesa (Les régles de la méthode sociologique, en Presses Universitaires de France, París).] 
Las reglas del método sociológico (1974). Buenos Aires: La Pléyade, 187 p. [Traducción de Aníbal Leal.]

Educación y sociología (1975). Barcelona: Península, 188 p. [Traducción de Janine Muls de Liarás de la original francesa publicada en 1973 por Presses Universitaires de France, París, extraída a su vez de la versión de 1922 publicada por la Librarie Felix Alcan. Introducción original titulada "La obra pedagógica de Durkheim», de Paul Fauconnet (p. 11-41). El libro presenta dos visiones opuestas del pensamiento durkheimiano, una en el prefacio (p. 5-9) de Maurice Debesse y la otra en el epílogo de Joan Volker "Fery, Durkheim, idéntica lucha» (p. 137-188).]

Educación como sociolización (1976). Salamanca: Sígueme, 274 p. [Traducción de Alfonso Ortiz García, Se trata de una versión de una edición italiana -dato que se escamotea al lector- que contiene textos de Éducation et sociologie, L'éducation morale y Sociologie et philosophie. Incluye una introducción (p. 9-27) de Nedo Baracani en la que se ubica a Durkheim y su texto en el debate sobre la enseñanza durante el laborioso período que atraviesa la escuela francesa a finales dle siglo pasado. Sitúa el libro en su contexto adecuado, tanto en el interior de su obra en conjunto, como en el debate sobre la nueva escuela laica republicana, primaria y superior. En las páginas posteriores a la introducción se presenta una breve nota biográfica del sociólogo francés, además de una bibliografía de sus obras y de los textos referentes a éstas.]

El suicidio (1976). Madrid: Akal, 450 p. [Introducción y estudio previo de Lorenzo Díaz Sánchez.]

Las reglas del método sociológico (1978). Madrid: Akal, 149 p. [Traducción de Antonio Ferrer Robert. Prólogo de Carlos Prieto Rodríguez (p. 5-13).]

Las reglas del método sociológico (1978). Madrid: Morata, 149 p. [Traducción de L.E. Echevarría. Segunda edición de una primera correspondiente al año 1974.]

La división del trabajo social (1982). Madrid: Akal, 491 p. [Traducción de Carlos G. Posada. Esta edición contiene un interesante estudio preliminar de Luis R. Zúñiga (Madrid, julio de 1979, p. I-XLVIII) donde establece una relación entre la vida y obra del sociólogo francés, situándola en su marco histórico. Analiza la relación radicalmente opuesta con la concepción marxista de la "estructura» y de su articulación con la «superestructura».]

Las formas elementales de la vida religiosa: El sistema totémico en Australia (1982). Madrid: Akal, 414 p. [Traducción y estudio preliminar de Ramón Ramos. Año de publicación del original en francés en 1912.]

Las reglas del método sociológico (1982). Madrid: Morata, 149 p. [Es la tercera edición, idéntica a las anteriores (1974 y 1978).]

Las reglas del método sociológico (1982). Barcelona: Orbis, 179 p. [Traducido por L.E. Echevarría Rivera. Se trata de una copia sobre la edición de Morata de 1982, que a su vez se extrae de la decimoctava francesa (PUF, París). Incluye una bibliografía adicional de los libros relacionados sobre el tema, así como una relación de revistas sociológicas.]

El socialismo (1982). Madrid: Editora Nacional, 322 p. [Traducción, introducción (p. 9-88) y notas de Ramón Ramos. En la introducción, Ramos menciona la costumbre de Durkheim de redactar íntegramente sus cursos académicos. Esto posibilita la publicación póstuma de varios de ellos y, en concreto, la recuperación de esta investigación sobre el socialismo. La finalidad académica del manuscrito explica la organización de texto en lecciones, así como su estructura expositiva, con sus típicos resúmenes y reiteraciones de orientación esencialmente didáctica. Al final 
de la introducción el libro presenta una bibliografía detallada (p. 91-96) de las obras de Durkheim en distintos idiomas, así como literatura diversa sobre el sociólogo francés.]

El suicidio (1982). Madrid: Akal, 450 p. [Se presenta como una primera edición, aunque ya se encuentra editada en Akal en 1976. Incluye una presentación de Lorenzo Díaz Sánchez en la que contextualiza el pensamiento de Durkheim en el marco de las ciencias sociales de la época. Lorenzo Díaz señala que el énfasis excesivo puesto por el autor de El suicidio en la realidad de la sociedad como algo separado de la realidad de los seres humanos, le predispone a la acusación de ensalzar la sociedad como una entidad mítica superior a la persona. El nombre de Durkheim ha sido (de forma equivocada) asociado a ideologías totalitarias. No obstante, el autor de la introducción invita a realizar una lectura atenta para demostrar la inconsistencia de dichas críticas. Al final de la presentación se incluye una bibliografía de las obras de Durkheim en francés, así como distintos estudios sobre el autor.]

Las reglas del método sociológico (1984). Madrid: Morata, 149 p. Corresponde a la cuarta edición y es idéntica a las tres anteriores (1974, 1978, 1982).

La división del trabajo social (1985). Barcelona: Planeta Agostini, 2 vol., 479 p. [Es la primera edición popular en esta colección. Es la traducción ya clásica de Carlos G. Posada.]

Las reglas del método sociológico (1985). Madrid: Akal, 156 p. [Traducido por Antonio Ferrer Robert.]

Las reglas del método sociológico (1985). Barcelona: Orbis, 188 p. [Traducida por L.E. Echevarría. Segunda edición de una primera de la misma editorial de 1982.]

Las reglas del método sociológico (1985). Madrid: Hyspamérica, 188 p. [Esta edición coincide con la de Orbis del mismo año.]

El suicidio (1985). Madrid: Akal, 450 p. [Es la segunda edición de una primera publicada en 1982. Incluye una introducción y un estudio previo de Lorenzo Díaz Sánchez.]

Las reglas del método sociológico (1986). Madrid: Morata, 149 p. [Traducido por L.E. Echevarría Rivera. Es la quinta edición. Incluye una bibliografia adicional de libros relacionados con el tema y una relación de revistas sociológicas.]

Las reglas del método sociológico (1986). Barcelona: Orbis, $188 \mathrm{p}$.

La división del trabajo social (1987). México DF: Colofón, 440 p. [Es la traducción del francés por Carlos G. Posada.]

Educación y sociología (1987). México DF: Colofón, 192 p. [Traducción del francés de Gonzalo Catajo.]

Las reglas del método sociológico (1987). Torrejón de Ardoz, Madrid: Akal, 156 p. [Traducción de Antonio Ferrer y Robert. Incluye un prólogo de Carlos Prieto Rodríguez (p. 5-13), en el que invita a conocer la obra de Durkheim y desentrañar su significado histórico. Para Prieto, Durkheim es un autor básico para entender la sociología contemporánea y las ciencias sociales. El método de la ciencia es inseparable de su objeto, algo que Durkheim pone de relieve y que el prologuista acentúa, además de formular afirmaciones rotundas acerca dle funcionalismo del sociólogo francés.]

Las reglas del método sociológico (1987). México DF: Fondo de Cultura Económica, 208 p. [Traducción del francés por Ernestina de Champourcin.]

El socialismo (1987). Madrid: 1987, 318 p. [Traducción del francés por María Esther Benítez Eiroa.] 
Las reglas del método sociológico y otros escritos sobre filosofia de las ciencias sociales (1988). Madrid: Alianza Editorial, 321 p. [Traducido por Santiago González Noriega, que también realiza una introducción (p. 7-25), finalizada con una pequeña bibliografía sobre las traducciones castellanas de Las reglas del método, así como de la metodología de las ciencias sociales en Durkheim en diferentes lenguas. En el último de los escritos recopilados aparece una pequeña y curiosa definición de Durkheim sobre el concepto de «sociedad» (p. 313) realizada en 1917, el año de su muerte.]

Educación y sociología (1989). Barcelona: Península, 188 p. [Traducción de Janine Muls de Liarás. Corresponde a la segunda edición de una primera de 1975.]

Montesquieu y Rousseau, precursores de la sociología (1990). Bogotá: Universidad Nacional. [Se trata de una edición traducida del inglés por Rubén Sierra Mejía. Es su tesis latina Quid secundatus politicae scientiae instituendae contulerit, presentada en 1893. En ella realiza un análisis a fondo de la obra de Montesquieu y de Rousseau. Esta tesis cambiaría casi por completo la forma de observar la sociedad como un monstruo formado por millares de cuerpos humanos (Leviatán). De ahí pasa Durkheim a considerar «el ser colectivo como un ser radicalmente diferente» ${ }^{51}$.]

Las formas elementales de la vida religiosa: el sistema totémico en Australia (1992). [Torrejón de Ardoz, Madrid: Akal, 423 p. Traducción del francés de Ramón Ramos.]

Historia de la educación y de las doctrinas pedagógicas: La evolución pedagógica en Francia (1992). Madrid: La Piqueta, 430 p. [Traducida por María Luisa Delgado y Félix Ortega de la versión original de Presses Universitaires de France. Es la segunda edición de una primera realizada en 1982. Este libro es la reproducción de un curso impartido por Durkheim en 1904-1905 y repetido los años siguientes hasta la Primera Guerra Mundial. En el momento de la reforma de 1902, se decide organizar en las facultades un cursillo pedagógico teórico para todos los candidatos a la agregación. A Durkheim se le confía la dirección de este cursillo en la Universidad de París. Incluye una presentación a la edición castellana (p. 7-17) por Félix Ortega. Se denuncia la anglosajonización de los textos clásicos y el hecho de que sólo se da relevancia a aquellas obras que han pasado por el proceso. No es el caso de este libro, ya que es editado por primera vez en 1939 y no llega a tiempo para que Talcott Parsons lo incluyese en La estructura de la acción social, por lo que los seguidores funcionalistas lo han ignorado. Félix Ortega realiza una crítica al funcionalismo ramplón que ignora que para Durkheim la historia es algo más que un mero instrumento auxiliar para la explicación de los hechos sociales. En este sentido, esta obra representa un texto fundamental para comprender la concepción histórica de Durkheim, pero resulta también imprescindible a la hora de enfrentarse con su teoría sociológica. Esta edición incluye también una introducción de Maurice Halbwachs (p. 18-23), que sitúa históricamente la obra de Durkheim.]

El suicidio (1992). Torrejón de Ardoz, Madrid: Akal, 450 p. [Es la tercera edición de esta editorial y se corresponde con las dos anteriores.]

La división del trabajo social (1993). Barcelona: Planeta Agostini, 2 vols. [Traducción de Carlos G. Posada cedida por Editorial Akal (1982). El primer volumen de 285 p. El segundo volumen de 222 p. se inicia con el capítulo primero del Libro II «Las causas y las condiciones».]

Las reglas del método sociológico (1994). Torrejón de Ardoz, Madrid: Akal, 156 p. 
Las reglas del método sociológico (1995). Torrejón de Ardoz, Madrid: Akal, 156 p. [Traducción de Antonio Ferrer y Robert. Corresponde a la cuarta edición. Incluye un prólogo (p. 5-13) de Carlos Prieto Rodríguez.]

El suicidio (1995). Torrejón de Ardoz, Madrid: Akal, 450 p. [Se trata de la cuarta edición presentada por Akal, idéntica a las anteriores.]

Educación y sociología (1996). Barcelona: Península, 188 p. [Traducción de Janine Muls de Liarás, Esta versión apareció anteriormente en la colección «Homo Sociologicus». Completan el volumen un prefacio de Maurice Debesse, una introducción de Paul Fauconnet y un epílogo de Joan Borrell. A pesar de que sus escritos pedagógicos permanecieron casi por completo inéditos durante toda su vida, tras su muerte fueron recopilados en tres volúmenes: Éducation et sociologie, L'Éducation morale y L'Évolution pédagogique en France. El primero de los cuales, publicado originalmente en 1922, es el que se ofrece en este edición.] 